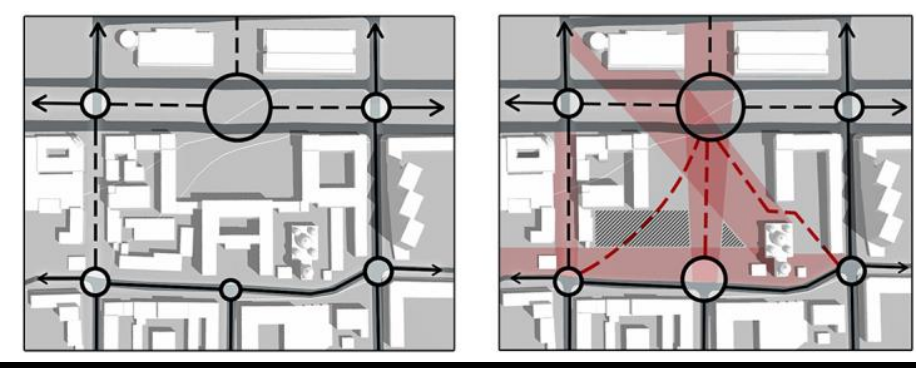

DOI: 10.21005/pif.2021.45.C-06

\title{
PERSPECTIVES OF THE PUBLIC SPACE DEVELOPMENT IN THE HISTORICAL PART OF DNIPRO, UKRAINE
}

PERSPEKTYWY ROZWOJU PRZESTRZENI PUBLICZNEJ W HISTORYCZNEJ CZĘŚCI MIASTA DNIPRO NA UKRAINIE

\section{Iryna O. Merylova}

$\mathrm{PhD}$, Associate professor, arch.

Author's Orcid number: 0000-0003-2019-0780

\section{Oleksandr A. Rechyts}

Senior lecturer, arch.

Author's Orcid number: 0000-0003-3105-7942

Prydniprovs'ka State Academy of Civil Engineering and Architecture (PSACEA), Dnipro, Ukraine State Higher Education Establishment

Department of Architectural and Urban Planning

\begin{abstract}
The article discusses the methods for reconstructing historical urban space of the industrial city of Dnipro in a post-industrial economy, strengthening globalization and digitalization processes of the social life of citizens, analyzing development milestones of the historical city center, identifying modern problems of the area under consideration and providing the ways to solve them as a conceptual project proposal.
\end{abstract}

Key words: reconstruction, re-functionalization, globalization processes, urban space, recreation, post-industrial city.

\section{STRESZCZENIE}

W artykule omówione są metody rekonstrukcji historycznej przestrzeni miejskiej przemysłowego miasta Dnipro w umowach kształtowania się gospodarki postindustrialnej, wzmocnienie procesów globalizacji i digitalizacji życia społecznego obywateli,przeanalizowane są etapy formowania i rozwoju historycznego centrum miasta ,zidentyfikowane są współczesne problemy rozpatrywanego terytorium oraz sformułowane sposoby ich rozwiązania w formie koncepcyjnej propozycji projektu.

Słowa kluczowe: przebudowa, refunkcjonalizacja, procesy globalizacji, przestrzeń miejska, rekreacja, postindustrialne miasto. 


\section{INTRODUCTION}

In recent years there has been an increased interest in the reorganization of city environment as a special type of architectural and art form, as well as urban planning activity. At the same time, the urban environment is perceived as a set of open architectural spaces with their subject-spatial content, which are intended for the life of population. On the one hand, the urban environment is interpreted as an open platform for the dialogue of cultures, intensified in the context of global communication and subject to pragmatic expressiveness. On the other hand, the unique character of the urbanized and architectural space of the urban environment demonstrates a certain cultural code of the city, based on traditions and national images, emphasizing the originality of the environment.

Global modern realities set a number of new tasks for the city. One of them is a new theory of the city, according to which a general concept of its development is formed, subordinating all spheres of the urban life (infrastructure, engineering networks, landscaping, etc.). The next one is the creation of a city brand as a media image, defined through a service system and urban public spaces. In addition, the urban environment is filled with associative cultural markers that define the urban space, making it unique in terms of cultural globalization. And, of course, a virtual urban environment is established.

Respectively, the issues of transformation and reconstruction of modern city environment taking into account the newest user-friendly engineering and social requirements mostly quantitatively than qualitatively are becoming relevant. The problem is especially acute in post-industrial cities due to preserving cultural heritage and acquiring new environmental qualities that correspond to the modern concept of comfort.

\section{MATERIAL AND METHODS}

The research methodology is based on theoretical methods of historical, literary, statistical, cartographic analysis, as well as the method of classification; empirical methods of comparative analysis; special methods of scientific knowledge: modeling and experimental design; on an integrated approach to solving complex urban planning problems. The research also explored an integrated approach, which made it possible to formulate a concept for the organization of public space on the territory of the historical center of the city, as well as to connect architectural, planning and territorial organization of the elements of this space. The use of this integrated approach to a specific architectural facility determined it, according to the authors, as a multifunctional public space (central square) in the structure of the city ensemble.

It should be noted that the research methodology is based on the works devoted to the history of architecture and urban planning; the urban environment of Dnipro, project proposals concerning the reconstruction of the city's central avenue, in particular; as well as redevelopment of the central square, architectural and urban planning concept of the city development, etc.

Moreover, the analysis of the historical and architectural reference plan helped reveal the value of historical buildings, as well as the boundaries of the historical area (International Center for Cultural Heritage and Property. 2019). The use of cartographic method made it possible to recreate the stages of formation, the degree of implementation and the development path of the master plan: from the idea of creating a city to its present state. 


\subsection{Historical analysis of the urbanized environment development}

Based on the methods of this study, the authors briefly represented the main milestones of the evolution of Dnipro, which determined the organization of the master plan, its development and layout (fig. 1):

- 1776-1880 - foundation of Yekaterinoslav and formation of its planning structure as an "urbanistic project of the Enlightenment", which was reflected in the features of a classic general plan (stringent geometry of quarters, trends of main compositional axes, location of squares and architectural dominants at their intersection points, etc.) (Revsky S. 1974, Revsky S. 1990, Yavornitskiy D. 1989).

- 1880-1914 - an industrial period, characterized by the development of engineering and transport communications and industry, the growth of urban population, the demand for a new standard of living and, as a result, a change in the architectural and urban planning of the city and the nature of urban development in general: the creation of complex urban buildings and new public spaces (Lavrov V. A. 1977).

- 1914-1941 - an interwar period is characterized by the strengthening of the industrial role of the city, restoration and formation of the first mass social buildings, construction of public facilities of a new type (palaces of culture, educational institutions) (International Center for Cultural Heritage and Property. 2019).

- 1945-1990 - a post-war period of the city's restoration, development of engineering and transport infrastructure, formation of new buildings and landmark objects in the era of Soviet modernism in the late 60 s up to 90 s and also reorganization of the central avenue (International Center for Cultural Heritage and Property. 2019).

- 1990 - a modern period, characterized by the loss of a significant part of environmental objects of the historical fund, as well as explosion and emergence of iconic objects of a new type (shopping centers, service facilities) along with new requirements for the quality of public spaces (Ukrainian State Research Institute of City Design "DIPROMISTO". 2019, Kavun M. E. 2005).

The historical analysis has shown the periodicity of development stages of Dnipro. Each of this period resulted in the town-planning design and layout of the city. However, the described periods did not get their logical conclusion due to various political, economic and other crises. The stagnation in the city development can be traced in between these periods, which entailed incomplete urban planning ensembles, difficulties in historically valuable buildings restoration, significant predominance of industrial buildings, as well as a significant shortage of high-quality public spaces: squares, boulevards and recreational facilities (Merylova I. O. 2019).

\subsection{Functional and environmental analysis of the territory of central city square}

The historical analysis of the stages of the city's development has redefined the nature of architectural and urban planning environment layout of the area under investigation. In particular, the area of the existing central square of Dnipro - Yavornytsky Avenue, Hrushevsky Street, Troitskaya Square, Korolenko Street, according to the original general plan by Starov and Geste architects, was a trading area with trade rows (temporary and permanent) and a wooden church of the Kazan Icon of the Holy Mother. Hence, initially the territory was intended for trade, religious and cult functions (Revsky S. 1983).

In the course of time, these trading rows were replaced by fundamental buildings and structures, but a group of quarters, which was originally a trading area with brick trading rows and a religious building (Trinity Church) in the inter-war period of 1914-1945, was used for production and administrative functions. In the post-war period, the central square was reconstructed, an architectural ensemble was built with the square as it is (in 1950-ies) (Revsky S. 1983, Revsky S. 1983). 

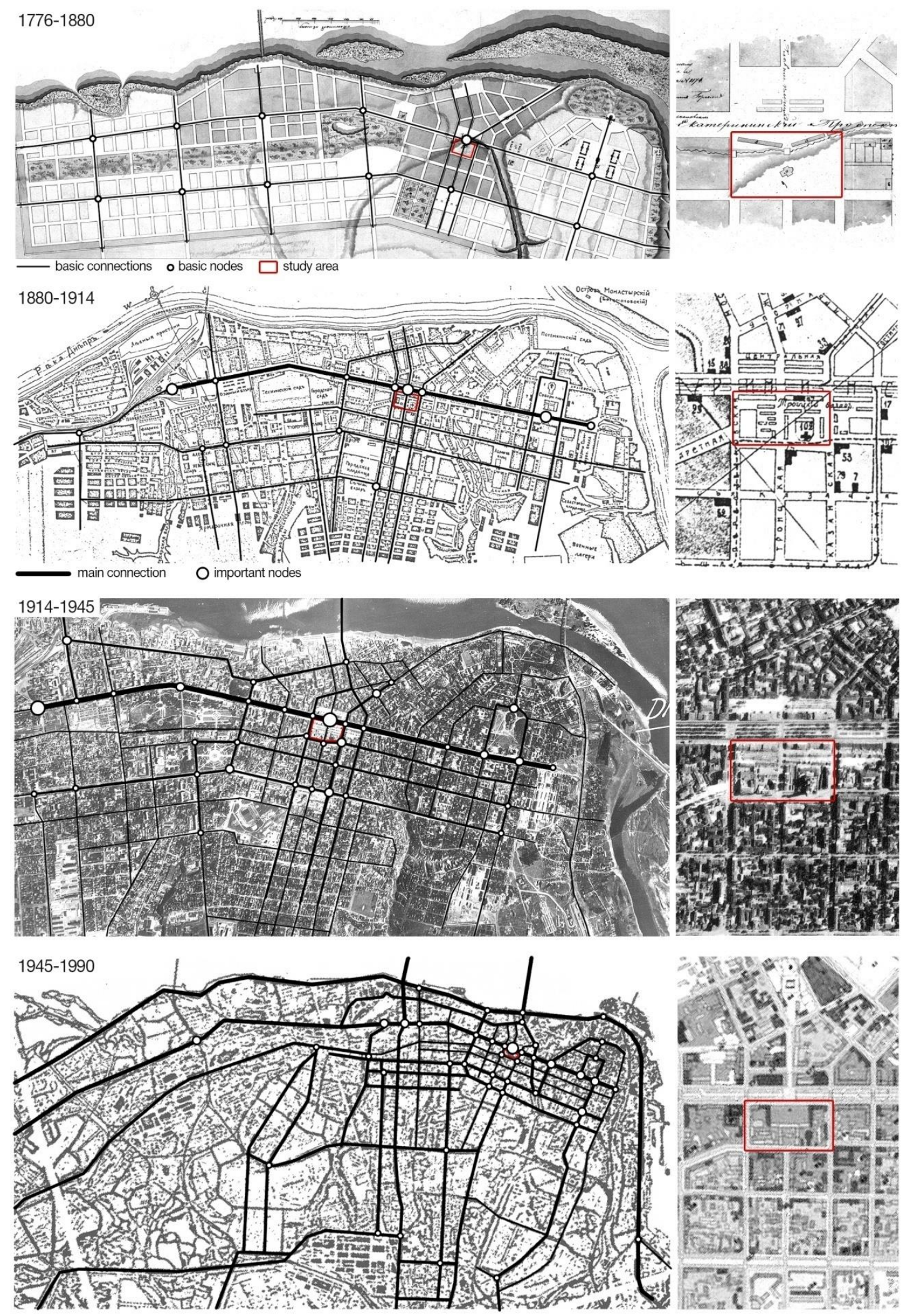

Fig. 1. Development layout of the central part of Dnipro including the territory of the central square. Source: https://gorod.dp.ua/inf/maps/ 
Eventually, the tendency to use territory with various functions continued to develop: complex of buildings for design institutes, the Ministry of Ferrous Metallurgy of the Ukrainian SSR, Center for consumer services, shops, as well as office buildings and service facilities in modern period - were built (fig. 2). As a result, the territory under consideration, which serves as the main square of the city due to its location, has become 'intimate', full with iconic objects of various historic periods of urban development, but not being formed into a single urban ensemble (fig. 3, fig. 4). Moreover, the underside of the architectural ensemble of the central square of the city is not expressive: the existing central building of the ensemble is of no architectural value (silicate brick and only one main facade is faced with ceramics). In addition, this architectural ensemble was the reason not to further develop the city in its transverse and in-depth directions (International Center for Cultural Heritage and Property. 2019). This approach reflected the policy of the state during the 50s, as the struggle against "architectural excessiveness".

Besides modern trends in the organization of public spaces, indicated above, the territory reorganization of the quarters of central square of Dnipro (Heroiv Maidanu Square) is justified by a number of features acquired by this space.

Fig. 2. Functional content of investigated area. Source: developed by Iryna $\mathrm{O}$. Merylova
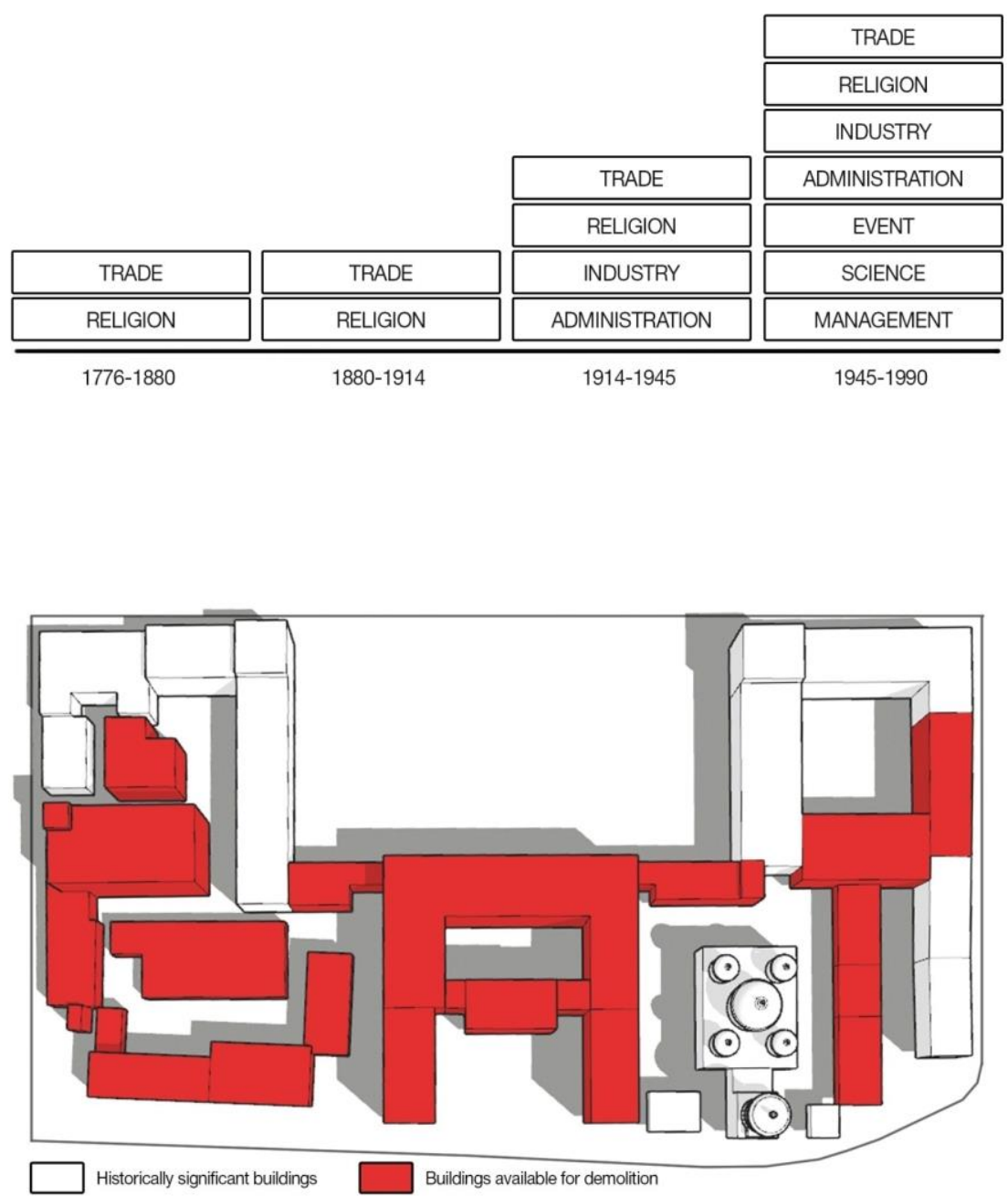

Historically significant buildings
Fig. 3. Scheme of historical value of architectural environment. Source: developed by Iryna $O$. Merylova 

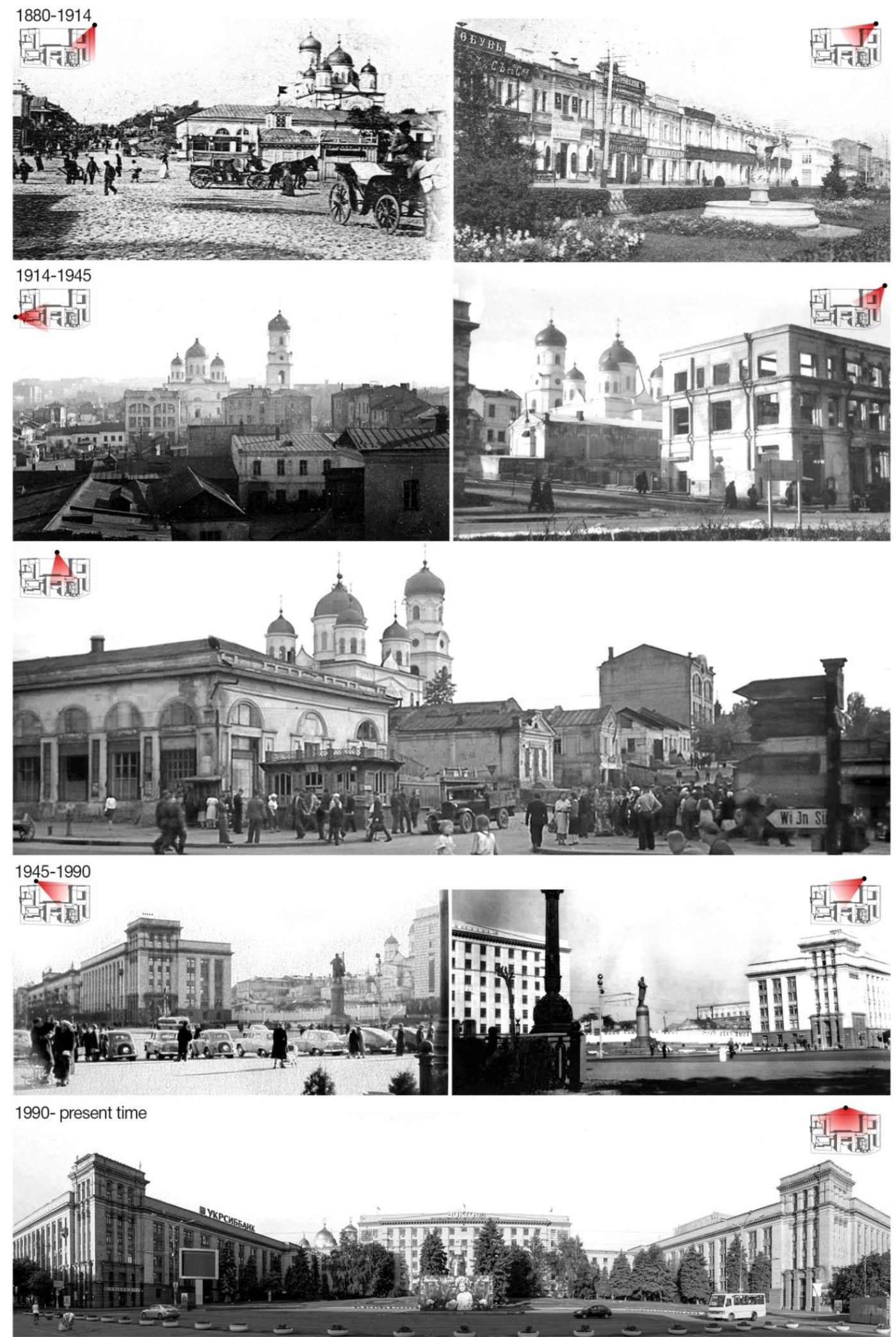

Fig. 4. Retro perspective of process formation and development of territory of the central square. Source: https://gorod.dp.ua/photo/theme.php?id=82 
First of all, it is a new functional purpose of the area (from a venue for local events: parades, political rallies, etc. to a recreational zone and a platform for public meetings) and functional content in its development (expansion of trade and office functions); lack of space for running cultural events, especially typical of the historical center area; lack of a sufficient number of recreational areas. The identified problems are the main reasons for the analysis of functional and planning organization of the historical city center and central square.

\section{RESULTS}

The use of the integrated approach served to define a clear urban planning problem - the existing urban development ensemble of the central square violated the original planning structure of the city and blocked the access to the central part of the city (Revsky S. 1981). As a result, an extended linear-nodal urban center was formed without any possibility to expand further development of the main social center, which could be formed into a full-fledged urban center later.

The solution to this problem by means of urban planning transformation is the most urgent today, since there is a shift from the linear-nodal center to a more complex one and less controlled structure, as a result of the established urban planning restrictions (Osichenko H. 2006). The city center area is 'oversaturated' with a number of functions inappropriate for local nodes, which 'erodes' urbanized environment, and doesn't make it possible to organize a hierarchy of central public spaces with functional content corresponding to their location in the city structure (Shimko V. T. 2006). In order to optimize functional planning structure of the City Square territory, the authors developed the concept of urban space reorganization, designed to resolve the urban planning problems of the designated area and, subsequently, create prerequisites for the further development of the city center (fig. 5).

The philosophical content of the concept assumes the restoration of historical justice in relation to the area of existing Central Square. The authors made a decision to establish a new multifunctional space connecting the main Square of the city (Heroiv Maidanu Square) with Troitskaya Square street and create a real Troitskaya Square which, in fact, is now nominally identified as a street. Such space reorganization could allow balancing scale of two spaces of quite different historical nature and creating a unique architectural object that will unite these public spaces in a loop, and will also become the hallmark of the city, as well as preserve visual axes of communication with the exposition of the territory (Merylova I. O., Sokolova K. V. 2020).
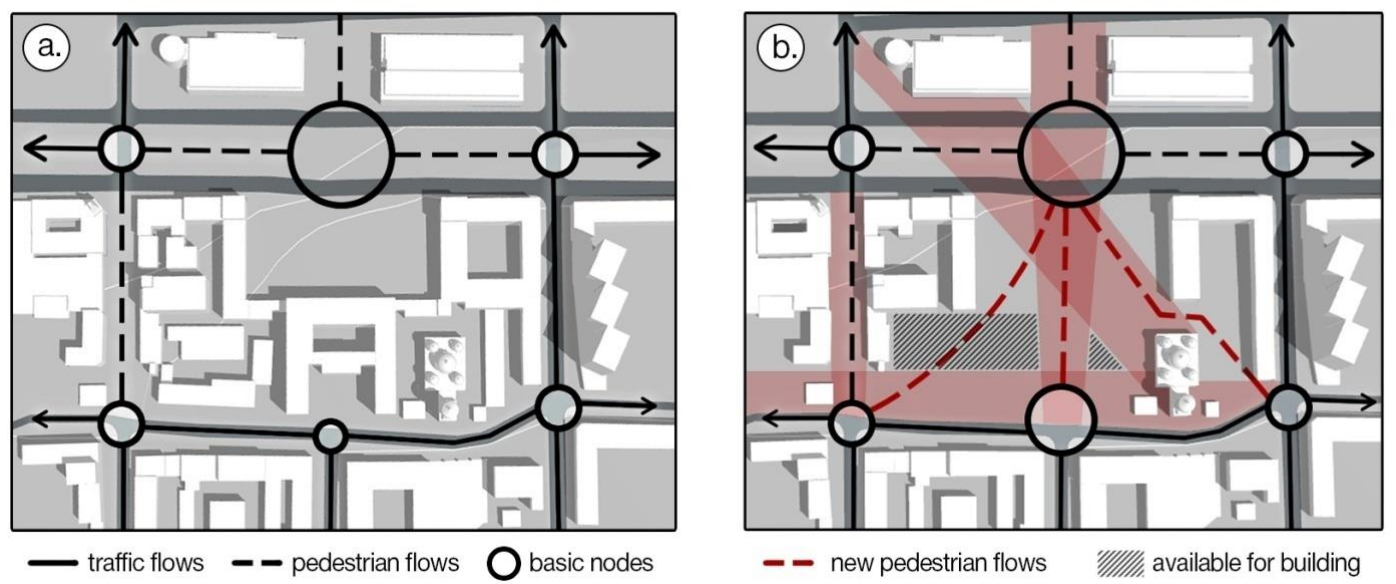

Fig. 5. Scheme of organization of transport and pedestrian communications of the territory: a. current state; b. proposed development. Source: developed by Iryna O. Merylova and Oleksandr A. Rechyts 
Two versions of the development of this hinge are presented for consideration. The intended function, of course, should be socially significant for the townspeople: the town hall, library, museum, congress center and multifunctional recreational spaces.

The first opinion. A contextual approach to the interpretation of urban space helps a new object to imitate a historically valuable building while maintaining the quality of a modern object. This solution preserves the status quo of the prevailing perception stereotype of the central square of the city and, at the same time, gives a smooth transition from new objects to the historical environment. It was necessary to overcome the multi-scale nature of the development of the central avenue and residential historical quarters (fig. 6).

The second option. A contrasting approach to solving this problem creates a new quality of the environment. The object itself becomes dominant and shapes up this environment, thereby uniting diverse spaces. It results in more scenery spots and composition axes. In the context of the current diverse development, such an object can become a new center of attention and can become an architectural and urban planning impulse that provokes rethinking of this space (fig. 7).
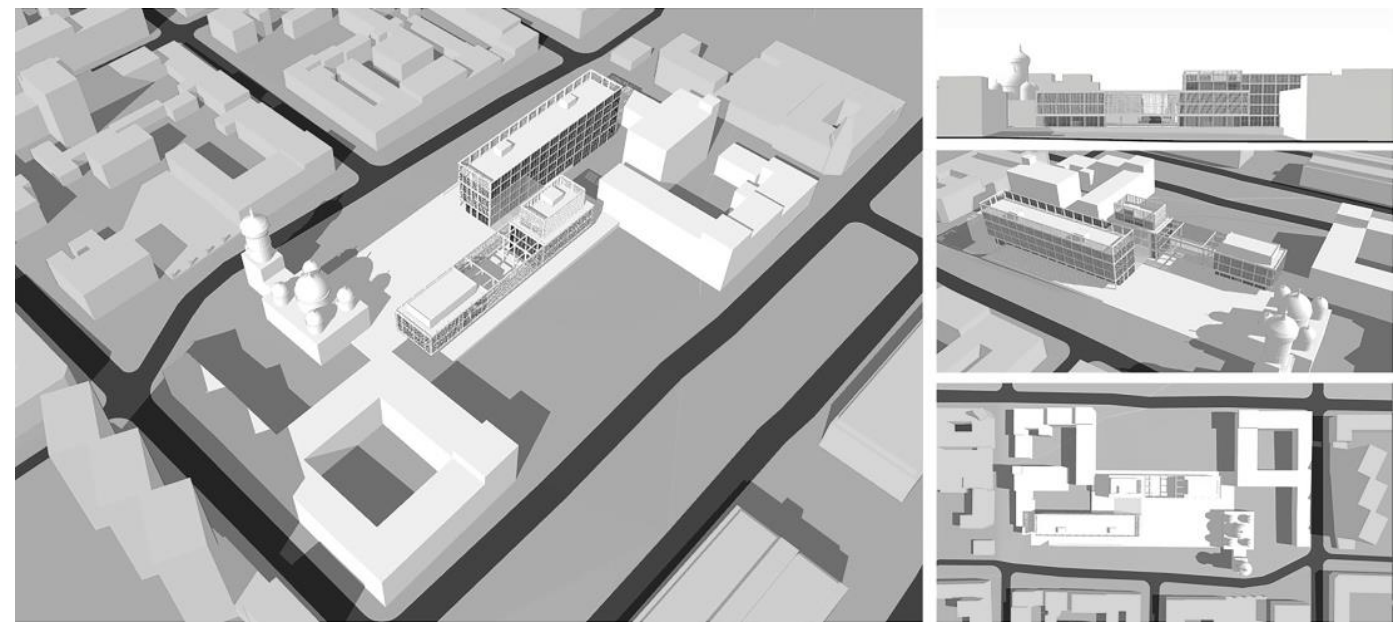

Fig. 6. Reconstruction concept of Heroiv Maidanu Square: contextual approach.

Source: developed by Iryna O. Merylova and Oleksandr A. Rechyts
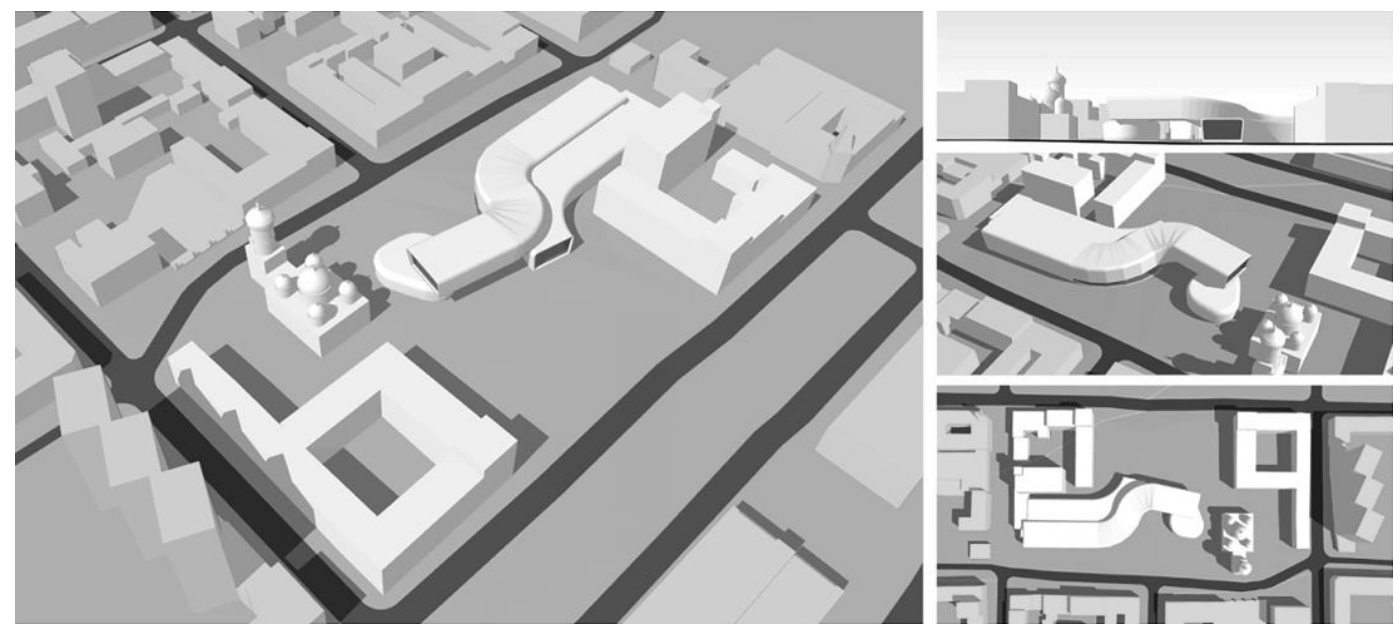

Fig. 7. Reconstruction concept of Heroiv Maidanu Square: contrasting approach.

Source: developed by Iryna O. Merylova and Oleksandr A. Rechyts 


\section{CONCLUSIONS}

The transformation of the city's community center has become a reality in recent decades. From a purely linear-nodal, in its structure, the social center is acquiring the properties of a more complex profound system, with the development of public spaces. This became possible due to the creation of pedestrian, street and public spaces duplicating the central avenue. Previously, all the attention in the architectural and artistic sense was paid to the facades of the center, oriented to the avenue, and the back side was given a secondary role. At present, this situation has changed. With the change in the functional purpose of buildings, with the expansion of the boundaries of public city center, it became necessary to bring public buildings to modern requirements and to remedy the situation that developed during the Soviet ideological period.

The authors consider that it is possible to change (demolish) the existing building that does not represent any architectural and artistic value and replace it with a more expressive and modern one. The authors suggest that the creation of the portal building will be able to accentuate new compositional axis of the city center: the central bridge - the European Square - the Square of Heroiv Maidanu - the Krasnaya Square - the Krasnaya Street and thereby expand the geography of the center to the historical quarters adjacent to the Krasnaya Street. The proposed solution will help to restore pedestrian communication with the central square and create pedestrian and recreational space with a high-quality environment and attractive for tourists.

\section{BIBLIOGRAPHY}

Andrushchenko N. P., Kavun M. E., Lopatyuk N. A. Dnepropetrovsk. Architects. Ed. Kandel-Perminova N. N. Kyiv: A+C, 2006. P. 18-24, P. 53, P. 57-58.

International Center for Cultural Heritage and Property. Historical and Architectural Reference Plan. Determination of Boundaries, Mode of Use, Modes of Regulation, Settings of Historical Areas of the City of Dnipro. Vol. 1. Kyiv, 2019. P. 35-64, 117-130, P. 238-240.

Ukrainian State Research Institute of City Design "DIPROMISTO". Architectural and Planning Workshop №1. Introduction of Changes to the Master Plan of the Place Dnipro. Explanatory Note. By O. Malysheva, O. Golovan', and Yu Paleha. Kyiv: Dipromisto, 2019. P. 134-136, Additions 206-217.

Kavun M. E. Genius of the Place. Part I. The Origins of Modern Dnepropetrovsk. Real Estate Movement, 2005. March 16.

Lavrov V. A. Development of the Planning Structure of Historically Established Cities. Moscow: Stroyizdat, 1977. $66 \mathrm{p}$.

Merylova I. O. Comprehensive Assessment of the Urban Ecological State of the City of Dnipro. Problems and Solutions. Urban Planning and Spatial Planning. 2019. P. 384-392.

Merylova I. O., Sokolova K. V. A Human In The Urban Space Of The Globalized World. Anthropological Measurements of Philosophical Research. Vol.18. 2020. P 113-120.

Osichenko $\mathrm{H}$. Methodical bases of reconstruction of compositional structures of historical cities (on the example of cities of Central Ukraine). Abstract diss. Harkiv, 2006.

Revsky S. B. About Attribution of the First Plans of the City of Yekaterinoslav. Collection of Abstracts of Scientific and Practical Conferences. Dnepropetrovsk: DNU. 1990. P. 55-57.

Revsky S. Architects, Engineers, Artists Participating in the Formation of Yekaterinoslav Late 18th Early 20th Centuries. Dnepropetrovsk: DCEI, 1981. 31 p.

Revsky S. Ekaterinoslav Kilchensky: A Historical Sketch. Dnepropetrovsk: DCEI, 1974. P. 18-33.

Revsky S. Formation and Development of the Historical Center of the City of Dnepropetrovsk. Monuments of Russian Architecture of Monumental Art. Moscow: Science, 1983. P. 264-265.

Revsky S. Historical and Architectural Development of Dnepropetrovsk and the Basic Principles of the Allocation of Protection Zones. Abstract diss. MArchl, 1983. 8 p.

Shimko V. T. Architectural and Design Planning of the Urban Environment. Moscow: Architecture S, 2006. P.146 -154, P. 322-350.

Yavornitskiy D. I. History of the City of Yekaterinoslav. Dnepropetrovsk: Promin', 1989. 57 p. 


\section{AUTHOR'S NOTE}

Iryna O. Merylova, $\mathrm{PhD}$, Associate professor, architect and urbanist in Department of architectural and urban planning at State Higher Education Establishment Prydniprovs'ka State Academy of Civil Engineering and Architecture (PSACEA), 24-A, Chernishevsky str., Dnipro, Ukraine, 49600. The main area of research: urban planning, landscape design, create of ecological urban spaces.

Contact | Kontakt: irina.merilova@gmail.com

Oleksandr A. Rechyts, architect, Senior lecturer in Department of architectural and urban planning at State Higher Education Establishment Prydniprovs'ka State Academy of Civil Engineering and Architecture (PSACEA), 24-A, Chernishevsky str., Dnipro, Ukraine, 49600. Member of the National Union of Architects of Ukraine (NSAU) and Architectural Chamber of Ukraine (ACU).

Contact | Kontakt: alexr@i.ua 